\title{
Developing an Angled
}

Perspective as Teacher

Educators: Using Narrative

Reflection to Disrupt the

Funding of Identity in Teacher

Education

Excelsior: Leadership in

Teaching and Learning

2021, Vol. 13(3), 214-231

(C) The Author 2021

CC-BY 4.0 International

Reprints and permissions:

surface.syr.edu/excelsior

https://doi.org/10.14305/in.1

9440413.2021.13.3.03

nyacte.org

\section{(D) Brittany A. Aronson, ${ }^{1}$ (i) Esther A. Enright, ${ }^{2}$ and (i) Tasneem Amatullah ${ }^{3}$}

\begin{abstract}
Building capacity in teachers to teach students skillfully and respectfully across the diversity gap is complex work that requires teachers to learn to see with what we term as angled perspective. If an angled perspective is learnable, then it is teachable. Using our narratives as religiously and ethnically diverse women teacher educators, we share through our own learning and growth, how this type of analysis can contribute to coalitional building for teacher education, and thus K-12 teachers. Through our conceptualization of identity theory, positionality, and intersectionality, we argue angled perspectives contribute to solidarity work in education. We share implications for teacher educators to integrate angled perspectives into curricula across teacher preparation courses.
\end{abstract}

\section{Keywords}

angled perspectives, teacher educators, positionality, intersectionality

Many scholars have noted that the U.S. population of practicing pre-service teachers (PSTs) is very homogeneous, especially along racial, class, and religious identities (e.g., Ladson-Billings, 2001; Liu \& Ball, 2019; Terrill \& Mark, 2000). Referred to as the diversity gap (Boser, 2014), researchers have

\footnotetext{
${ }^{1}$ Miami University

2 Boise State University

${ }^{3}$ Emirates College for Advanced Education, Abu Dhabi, United Arab Emirates Authors contributed equally to this manuscript
}

Corresponding Author: Brittany A. Aronson, Miami University, 304 McGuffey Hall, Oxford, OH 45056 Email: aronsoba@MiamiOH.edu 
documented that this teaching population tends to be predominantly women from white, monolingual, middle-class, Christian upbringings, while we have an increasingly diverse generation of school-age children, many with identities that differ from those of their teachers. In short, teacher education, and thus teacher educators, need to increase our capacity to interact equitably across identity differences as well as develop greater capacity to prepare future teachers to do so as well with their own students. Building capacity in teachers to teach students skillfully and respectfully across the diversity gap is complex work (Milner, 2010) that requires teachers to learn to see with what we term angled perspective. If an angled perspective is learnable, then it is teachable. Using our narratives as religiously and ethnically diverse women teacher educators, we share through our own learning and growth, how this type of analysis can contribute to coalitional building for teacher education, and thus K12 teachers. Through our conceptualization of identity theory, positionality, and intersectionality, we argue angled perspectives contribute to solidarity work in education.

We begin with a review of the literature on teaching and teacher education to situate the need for this work, and then move into our conceptual framing building from work of identity theory, positionality, and intersectionality. We argue that building capacity to become critical educators is complex work that requires teachers to learn to see with what feminist scholars have termed "angled vision" (Bailey, 1998; Belkhir et al., 1994; Collins, 2015). We want to honor the lineage of this with work, but will instead refer to "angled vision" as an "angled perspective" to disrupt our reliance on ableist language. We argue there is a need for us as teacher educators to foster an angled perspective for PSTs within our classrooms and use our stories as examples for what this might look like. We share implications for teacher educators to integrate angled perspectives into curricula across teacher preparation courses.

\section{Literature}

Teacher education needs to be responsive to the changing landscape of U.S. schooling by preparing an overwhelmingly white teaching force to teach an increasingly racially and ethnically diverse student population with skill and respect (e.g., Darling-Hammond, 2011, Liu \& Ball, 2019). This is not a new reality for U.S. schooling, nor has this always been the case. Since the 1960s, the school age population in the U.S. diversified across many dimensions, particularly across racial, ethnic, and religious identities. Gloria Ladson-Billings (2001) wrote

Not only [will teachers encounter] ... multiracial or multiethnic [students] but they [students]

are also likely to be diverse along linguistic, religious, ability, and economic lines.... Today teachers walk into urban classrooms with children who represent an incredible range of diversity" (p. 14).

This is also true for increasingly diverse rural classrooms as well (Tieken, 2014).

Yet, the teaching force remains composed of predominantly white, monolingual women, creating a growing "mismatch" (Terrill \& Mark, 2000) between students and teachers. Logically, the overrepresentation of white, monolingual women in the teaching force assumes the underrepresentation of other groups. Of particular concern is the underrepresentation of teachers of color. This underrepresentation is not accidental, but rather has deep, historical roots, including the dismantling of schools serving Black students and the firing of Black teachers and administrators in the aftermath of the Brown versus The Board of Education of Topeka, Kansas decision in 1954 (LadsonBillings, 2004). The growing diversity in the K-12 student population and near absence of diversity 
along similar lines in the teaching workforce creates a particular set of challenges and needs that must be explicitly addressed by teacher education and by us as teacher educators.

An important factor influencing changing teacher dispositions is self-reflexivity. Garmon (2005) defines self-reflectiveness as, "having the ability and willingness to think critically about oneself" (p. 277). Furthermore, Howard (2003) believes, "to be culturally relevant, teachers need to engage in honest, critical reflection that challenges them to see how their positionality influences their students in either positive or negative ways" (p. 197). Additionally, Gay and Kirkland (2003) explain, "... teachers knowing who they are as people, understanding the contexts in which they teach, and questioning their knowledge and assumptions are as important as the mastery of techniques for instructional effectiveness" (p. 181). Gay and Kirkland (2003) found that some PSTs were resistant to being selfreflective, especially in terms of race and cultural issues and were unwilling to examine their own biases and stereotypes. Sleeter (2001) explains many PSTs embrace colorevasive approaches in order to distract from differences and bring the idea that we are all equal to the classroom. Similarly, Ullucci (2012) findings showed PSTs struggle to make sense of race, especially without spaces for reflection. Over the course of four years, she conducted a document analysis of 110 PSTs autobiographies with a focus on race and culture. The assignment allowed a space for white teachers to understand their identities and how whiteness focused in society, which is an important first step in engaging with critical reflexivity. Additionally, in a course entitled, "Identity and Teaching," Howard (2003) engaged his preservice teachers in readings pertaining to racial, ethnic, gender, and social class identities. He found that many of the students came to value critical reflection and how it aided them for teaching in culturally responsive ways.

Thus we argue that teacher education can play a critical role in preparing new teachers to teach across differences (Milner, 2010). Yet, we recognize the "enormous gap between who prepares teachers, who the teachers themselves are, and who they will likely teach...that results in a significant detachment of White teacher educators and White teacher education students from children of color" (Cross, 2003, p. 204). We align our work with other scholars that view underserved students as in possession of funds of knowledge (Moll et al., 1992), which white teachers often fail to recognize and leverage in their instruction when teaching students across identity differences (Delpit, 2012). We also believe that teaching students across identity differences is learnable, and thus teachable. Those foundational assumptions lay at the foundation of the argument we advance in this paper that teacher education is failing in its mandate to prepare teachers to step into diverse classrooms ready to teach students equitably across identity differences. Compounding the challenging nature of these demands on teacher educators' professional learning, there are few opportunities for teacher educators to engage in specialized professional development. We believe this dearth of opportunity is an opening to use critical teaching frameworks for teacher educator reflection, toward the aim of building capacity for PST reflection as well.

\section{Critical Teaching Framework for Teacher Reflection}

As we asserted above, while we acknowledge the existence of the "diversity gap," and we know that this contributes to cultural mismatch between teacher and students, we do not assume coming from differing backgrounds means a teacher will automatically fail their students. We also believe that this extends beyond the highly cited "diversity gap" of white women teaching students of color to also include straight teachers and queer students, monolingual English speaking teachers and bi/multi- 
lingual students, Christian-identified teachers and students of other religious backgrounds or nonreligious identities, and teachers who are able-bodied with students who are differently abled (dis/abled). These divides can exist across multiple identity markers and thus it is crucial to have a comprehensive and thorough understanding of the socio-historical-political context of schooling and how that influences education today. We assert that a very important first step in beginning to bridge these gaps is through critical reflection and gaining an understanding of the self in relation to the world (Gay \& Kirkland, 2003; Howard, 2003). This is not to dismiss the enormous amount of additional historical context and (re)learning that teachers must do in relation to content (i.e. learning Black history or women's history; Love, 2019), but for our purposes, we are going to focus on lessons of critical self-reflection. Below we highlight the theories that inform us when teaching in social justice multicultural education courses related to critical reflexivity. For our students to think critically about their identities, they have to work to understand themselves first. We believe teachers have the capacity to learn to be socially just.

\section{The Capacity for Angled Perspective Taking}

The contributions from the scholarship on identity theory, positionality, and intersectionality all advance the development of an angled perspective as educators when part of a process of ongoing, critical reflection. To build on previous work on the concept of 'angles of vision' and to foster our growth as critical teacher educators, we advance a new framework for developing capacity as teacher educators to interact across identity differences - our theory of angled perspective. In agreement with Belkhir et al. (1994), "...the history of women of color gives us the best model on which to develop a multicultural education that considers race, gender, and class as the central focus in all disciplines" ( $p$. 7). Building from positionality and intersectionality theories that are developed from women of color is an important starting point to consider multiple vantage points. An angled perspective also implies a type of "enlightenment." This is not to suggest that by developing an angled perspective one is "allknowing" or without anything further to learn; the theory acknowledges the benefits from an appreciation of multiple perspectives and how this contributes to the growth of critical consciousness. Collins (2000) explains, “... dialogues among African-American women and other historically identifiable oppressed groups should benefit from the multiple angles of vision that accompany multiple group standpoints" (p. 249).

We understand angled perspective as a practice that operationalizes positionality theory - where educators leverage their awareness of the complex relationship between their own identities and systems of power (intersectionality). In turn, they use that awareness to recognize their students' complex realities and access to resources, especially across identity differences. We argue a welldeveloped awareness of one's own identities, positionality, and intersectionality, is needed to build capacity for angled perspectives, the practice of seeing from one's angles of perspective (e.g., Belkhir, 1994; Bailey, 1998; Collins, 2015). Importantly, our individual explorations of our stories further reinforced when we put ourselves in conversations with one another increasing our capacity to consider other viewpoints and perspectives. As Collins (2015), "shared experiences can foster similar angles of vision leading to group knowledge or standpoint deemed essential for informed political action" (p. 300). By working through our learnings of positionality as educators, this contributes to our understanding of difference and how this can enhance our abilities to work in coalitions across differences. In turn, this allows for us to model this sort of solidarity building with PSTs (see Figure 1). 
Below, we expand upon each of the theories- identity, positionality, and intersectionality- and we use our own narratives as examples of each of these theories.

\section{Building Capacity Through ldentity Theory}

As seen in many social justice types of courses, we have students complete different variations of identity wheels to bring to consciousness the types of social identities they possess. Beverly Daniel Tatum (2000) explains that the concept of identity is "complex and shaped by individual characteristics, family dynamics, historical factors, and social and political contexts" (p. 9). She argues that while we have individual perceptions of who we are, which vary with dominant versus oppressed identities, this is often mediated by other's perceptions of ourselves. The parts of our identity that tend to capture our attention first are those typically marginalized in society- simply put, those who fall outside of a white, Christian, cishetero norm are actively aware of it. Gordon (2005) exposes the cost of not preparing white teachers to disrupt these oppressive beliefs, transmitting them instead in a plethora of ways to students. For example, Geneva Gay (2002) describes the burden on students of color in schools, who find themselves in "double jeopardy-having to master the academic tasks while functioning under cultural conditions unnatural (and often unfamiliar) to them" (p. 114). Yet, the question remains - do teacher educators, who are also mostly white, Christian women, (Johnson, 2002; Talbert-Johnson \& Tillman, 1999) have the capacity to unpack their own identities, in particular their whiteness, and resources to support teachers in that work?

\section{Figure 1}

Image of Combined Theories

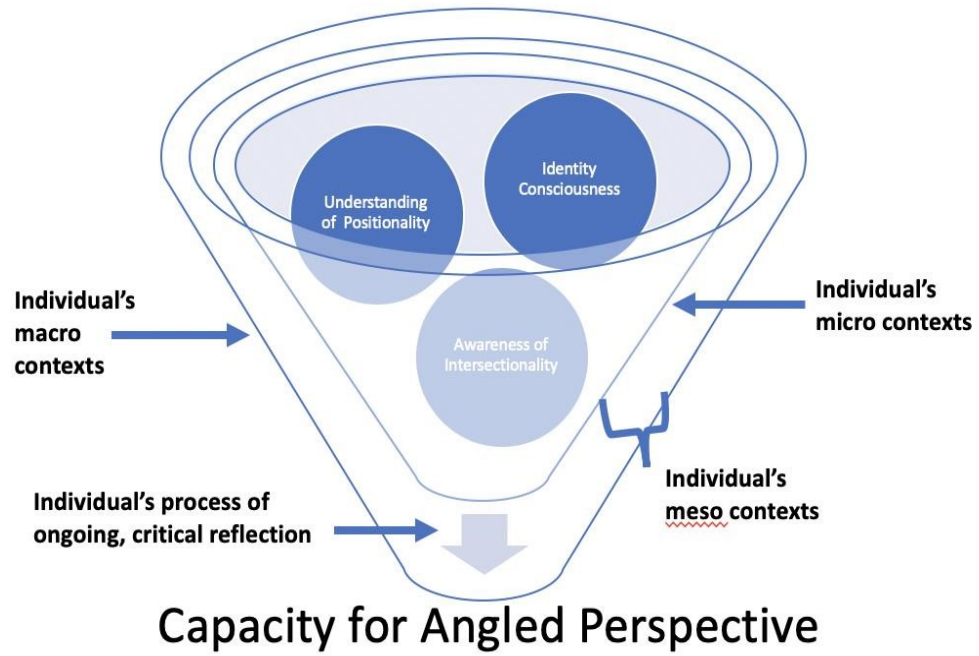

In 2003, a special issue of the International Journal of Qualitative Studies in Education(QSE) consolidated the research on white teacher identity development (WTID; Marx, 2003). Jupp et al. (2016) termed this period of work "first-wave white teacher identity studies" which referred to the research that documented the extensive amount race-evasive studies describing "white teachers' evasions, resistances, and denials to the saliences of race, white identities, white privileges, or whiteness inherent in knowledge and social institutions" (p. 9). For example, in their research Irvine (1990) and 
King (1991) found white teachers hold deficit views of Black children. A decade later, Sleeter (2001) still found that white preservice teachers often were not cognizant regarding issues of race, held stereotypes about people of color and had little understanding of their role in perpetuating racism. These foundational studies led to an emergence of research that directly named injustices in teacher education, a call to action to address white privilege and much needed discussion of where the field of teacher education was heading (Jupp et al., 2016).

First-wave studies pushed researchers to move beyond documenting white teachers' aversions to conversations of racial privilege in new directions that encouraged a deeper analysis of critical reflexivity, privilege, and oppression. Jupp et al. (2016) conducted an extensive review of the literature on WTID from 2004-2014 which they termed "second-wave white teacher identity studies" with a purpose of advancing new concepts that addressed earlier critiques (pp. 11-12). Of the 65 studies reviewed, 20 of the studies still emphasized race-evasiveness from white teachers, but reflected "new methodological epistemological directions, increased researcher reflexivity, future conceptual refinements, and fertile paradoxes" (p. 18). Importantly though, the other 45 studies highlighted "racevisible White teacher identity studies instead began to carefully illuminate White teachers' understandings of race, class, culture, language, and other differences in personal and professional contexts" (p. 18). For example, within their synthesis, Jupp et al. (2016) found "studies focused on whiteness pedagogies began to demonstrate that non-essentializing identity understandings available in autobiographies and teacher identity narratives played an important role in the development of racevisible recognitions or conscientization" (p. 24). They advocate for the continued need for teaching and learning about race, whiteness, and white identity in teacher education.

This identity work in teacher education is an important first step to understand how to work with a predominantly white teaching force in an increasingly growing diverse student population. However, this work places an emphasis on racial identity, with seemingly less emphasis placed on other social identities that PSTs possess. Additionally, identity research with PSTs of colors can be overshadowed in teacher education given the focus on white teachers; while much needed, this can re-center whiteness in ways not intended. Aronson focuses on the initial learning of her social identities and how they interact with one another, including learning about her privilege, but also the ways that she internalized whiteness.

Aronson. One of the things you are forced to think about when you teach students about identity and positionality is your own identity and positionality. Early on in my career, I wrote simplified "positionality statements" in my writing. They looked something like this: I'm a white, middle class, woman. For one, I only thought about myself in the racialized way that I was raised in culturally and ethnically diverse South Florida. Two, I rarely thought about my other intersecting identities (not to be confused with intersectionality) that I possessed in terms of sexuality, ethnicity, religion, ability, geographic location, or educational status. In other words, as so many critical scholars do, Ichecked "my boxes" and moved from there. However, there was something not quite right about the way my "boxes" allowed me to navigate this world.

Early on in my own teacher education, I was confronted with the idea of white privilege and immediately rejected it. Years later, when I returned to pursue my doctorate, taking a course in Critical Race Theory (CRT) no longer allowed me the luxury to ignore my racialized and ethnicized identities, nor the privilege attached to them. As part of the larger project of white supremacy, I began to understand that while I am privileged in my ability to "pass" for white in many spaces, I dismissed an entire part of my existence because I could. I could no longer teach courses on social justice and ask my 
future teachers to grapple with their identities, if I continued to hide mine. I had to address my Colombian heritage on my mother's side and what this meant to me as a 'white' female who grew up near Miami, Florida. For me, my identity is still complicated in the ways I was socialized growing up (which I explore in other publications, Stohry \& Aronson, in press), how I am now read by others, and how it shapes my experience living in the Midwestern U.S. It was, and still is, necessary to always own my privilege as a racially white woman, but also to recognize that by denying my Latin American heritage, I was further reinforcing whiteness.

Also, it wasn't untilgraduate school that I was obligated to confront oppression related to gender, sexuality, and religion. I find it fascinating that a field dominated by women does not have a stronger community committed to studying gender dynamics in teacher education. Furthermore, with this being a field dominated by white women, the need for intersectional analysis is even more critical. My graduate classes exposed me to literature on LGBTQ youth that I had never been asked to think about before. While I was relatively more prepared to think about diversity in terms of race and language, I barely had exposure to how I would go about teaching queer youth or be culturally responsive to queer youth's needs in my classroom. I didn't seek out any of these resources either. This was probably related to my conservative Christian upbringing that taught me being gay was wrong. I think deep down I always rejected that thinking, but it took me time to unlearn these deeply-seated and reinforced beliefs. My views on sexuality were deeply connected to my religious socialization. However, Idon't want to suggest that just because someone identifies as Christian this automatically means they are homophobic. I also thought that as I was becoming "socially justice liberated" I would have to give up my faith and become agnostic. I have been fortunate enough to have friends in my life who are both Christian and identify as LGBTQ or as an ally. This taught me the ways people take up their spirituality can vary within any faith-based system. I grew to be comfortable owning my roots in Christianity and the role that spirituality plays in my life. Love is the most important takeaway from Christianity, and I know this is something shared across many faith communities.

As a racialized white Latina, U.S. citizen, Christian spiritual, cis-hetero female, who is middle-class and able-bodied, I recognize that my intersecting identities influence my position in society. I am very privileged when thinking about systems of oppression in the U.S. in most ways. It's important to story these experiences with students as a means to share the nuances that exist when discussing identity and positionality. Also, when modeling this, I illustrate the growth that I have experienced over time, and the growth that I still have to do.

We assert that confronting identity is an important first step for teachers who are learning to be selfreflective and critical in their understanding of privilege and marginalization. While identity is not always stagnant, and formed around socially constructed categories, there are important implications for how we construct identity. McLaren (1997) states "identity choices are structured by class, ethnic, and gender stratification, objective constraints, and historical determinations. Put another way, individuals and groups are inevitably located, and often differentially constrained, by wider structural forces such as capitalism, racism, colonialism, and sexism (p. 6). Importantly we must acknowledge that identity is messy and does not always fall into neat boxes (as Aronson and Enright share). We believe identity work is an important first step, but insufficient alone. This is where positionality and intersectionality can help us further. 


\section{Building Capacity Through Positionality Theory}

Understandings of identity inform the way that we operationalize positionality in our education courses. Essentially, positionality recognizes that people can have both similar and different vantage points from which they see the world, and these vantage points stem from a person's experience that is defined by social group membership (Collins,1990). Positionality theory originates from "standpoint theory" stemming from feminist work of the 1980s and 1990s seeking to understand how men and women view the world differently as well as acknowledge a misconception of neutrality in research (Haraway, 1988; Harding, 1986, 1991; Wood, 1992).

In the education literature, the term "positionality" has been taken up to acknowledge a person's social identities and how they are positioned in society. As explored with identity, positionality considers all raced, classed, gendered identities as contextual and "relational, complex, and fluid" (Martin \& Van Gunten, 2002, p. 46), rather than "essential qualities" (Alcoff, 1988; Bartlett, 1990, Haraway, 1988; Maher \& Tetreault, 1993, 1994). Sensoy \& DiAngelo (2012) define positionality as "the recognition that where you stand in relation to others shapes what you can see and understand about the world" (p. 8).

We have come to see positionality as a stepping stone to understanding power. Who you are in relation to your intersecting identities is influenced by the context of how you are positioned in society. In other words, we each have our "single stories" (Adichie, 2009), but these are contextual in the larger society that we are all members of. Individually, the theories that we connect in our angled perspective framework - identity, intersectionality, and positionality - forefront people's social identities and help them make sense of the realities they confront due to those identities, yet separately, these theories do not necessarily support individuals' capacities to understand others' identities and realities. This angle of perspective, leveraging our understanding of these three theories together to develop awareness of others, is essential to interacting and communicating across identity differences in teaching. This next narrative focuses on and models the role positionality theory plays in angled perspective taking. Enright reflects on the complex positionality her own identities afford her as a teacher educator. She problematizes the focus on privilege over power when talking about identities and systems, especially regarding her Jewish identity which is often misrepresented and essentialized as solely a religious affiliation.

Enright. After three decades of examining my own identities across three countries in which Ilived (Israel, Poland, and the U.S.), I thought I had arrived at a "self-definition" - a cis-hetero white, Jewish woman, who is both able-bodied and living with trauma. I also identify as multilingual, multinational, and middle class as well as a child and grandchild of refugees and Holocaust survivors. I have aunts, uncles, cousins, and friends who are Jewish and not white. I could see the difference in our experiences both outside and within Jewish communities. I had been told by people within and without those same Jewish communities that being Jewish is a religious identity and invisible to others - making me a part of a hidden minority. Yet, the idea of my Jewish-ness being hidden to others and purely a religious identity did not align with my lived experiences.

Igrew up with a rich sense of my Judaism. My parents, grandparents, teachers, and friends enveloped me with a rich tapestry of language. I played cards with my grandfather in Yiddish; cooked with my great aunt and cousins in Hebrew and French; celebrated Hanukkah with songs in Ladino; chanted prayers in Hebrew and Aramaic; fell asleep to stories in English, and got my mouth washed out with soap for swearing in most of those languages. I was raised on Yiddish music, comedy, and theater. 
Preparing food was one of the ways I learned our oral traditions. Food was a large part of my Jewish heritage, and not in a shallow, casual way. Ilearned about my grandparents' lives before and during the Holocaust while baking with them. I heard my great aunts'stories about growing up in Algeria before they were exiled while preparing couscous from scratch. Friends brought my family food to comfort us when my Bubbe (grandmother) and later Zadie (grandfather) died. My grandparents instilled a very Jewish sense of magic and mysticism in me. We also grew up going to shul (the Yiddish word for synagogue), and while important, that religious expression was only part of my Judaism.

My Jewish experience extended beyond joyous, cultural interactions. I attended a Jewish elementary school in the U.S., and I remember the intense fear and changes in school routines during the neo-Nazi rallies in the 1990s. We had armed guards at the door to all the Jewish schools and synagogues I attended. I have visceral memories of my grandmother stepping in front of me in fear when we were approached by a police officer on the street. My grandparents and parents were afraid of police and military officials - they coached us to avoid them when we could and be deferential when we could not. When I was in kindergarten, I came home from school after listening to a Holocaust survivor tell her story, and my mom asked me if I was scared. I told her, no more than before; as a five-year old, I already knew about our family and people being hunted and murdered for being Jewish. There were smaller signs that my Jewish-ness was othering too. My non-Jewish friends commented on the "ethnic food" they tried when they were at my house for meals. The women at the make-up counters could never match my olive skin tone to the choices of foundations available. The people who cut my curly hair insisted on straightening it so I would look pretty. The Jewish characters in movies and tv shows were always neurotic, infantile, and wealthy - they were never the protagonists in those stories either. Doctors shamed me and my parents for our inability to provide more complete medical histories. Teachers insisted that since my parents were born in Italy and Germany (as refugees in camps without citizenship) that I should just choose one of those countries for genealogy projects and stop being difficult. The box we call religion has always been too small for my Jewish experience and identity.

Then, four years ago just before the 2016 election, I moved to Idaho for my first faculty position. I began to ask, how could I claim white privilege but struggle to race myself as white.

After I read Eric Ward's (2017) article about his experience as a Black man investigating the theoretical core of white nationalism, I began to truly appreciate the complexity of my Jewish identity. Ward argues that it was time for "White'Jews to contemplate the provisional nature of their Whiteness, their privilege. Privilege, after all, is not the same as power. Privilege can be revoked" (p. 7). He claims that antisemitism is a core ideology of white nationalism and that Jews are racially constructed as outsiders twice - not white but also not people of color. Like others (e.g., Rubin, 2017), being raced with my family and people's oppressors as white, European is painful for me, although whiteness reflects many aspects of my lived experiences in the U.S and Israel (although not in Poland).

In 2016, I began having difficulty claiming whiteness, although I readily listed examples of my white privilege. Istarted acknowledging the times and ways my privilege was revoked. Outside of work, I have been pulled over more often by the police out west than I have ever before in my life and with a level of hostility that surprised me (a sign of my past white privilege). I was never stopped for speeding or dangerous driving - but for reasons that I could not explain, nor were they explained to me one police officer asked me to hand him my sunglasses, so he could check that they were in fact prescription lenses as mandated by my driver's license. At the university, my colleagues have made explicit antisemitic jokes and evoked damaging stereotypes to my face in faculty meetings. I have phrases, such as "you people" and "Jew-ed down" hurled at me. I have also reported them with no action taken. I have asked colleagues to remove their fingers from my curly hair and patiently explained 
why holding events on major Jewish holidays is unacceptable. Adding to my confusion, I was invited to join the faculty of color affinity group at my university. I lost count of the types of recognized and unrecognized service roles I have taken on trying to protect and nurture students with targeted identities and educate other faculty so they would be better prepared to do so as well. I have not arrived at a new "self-definition" of my identity, but I have developed new tools, knowledge, and dispositions that help me consider my identities and identity as a larger construct.

Iecho my co-authors' thoughts on the value of these complex experiences in my work as a teacher educator. The more I have explored the complex intersections of my identities, consider the "interplay of positionality" in respect to the systems we all navigate (Sensoy \& DiAngelo, 2012), and the dynamic, contextualized nature of social identity the better I am equipped to support my students in their development of their own understandings of identity, positionality, and intersectionality as preservice teachers. Race, as other social identities, are "fully funded by the society" (Ladson-Billings, 2018, p. 92). Ladson-Billings asks, "what does such funding mean in schools and classrooms?" (p. 95). Preservice and practicing teachers, teacher educators, school leaders, and other school personnel have a unique role in the society.

We work for and make up an institution that legitimizes society's funding of race and other identities. We also exist as change agents within that system. We shape the future. Our self-knowledge, worldviews, and capacity to challenge how identities are funded matter. I hope the vulnerability in which I and my co-authors share our stories and how our understanding and telling of those stories has changed helps others question and disrupt how identity is funded in teacher education and schools.

Although the fact of having different positionalities can easily be conceptualized, it may be rather difficult to grasp a concrete realization of our own positionalities and the benefits or struggles we have faced due to them. Takacs (2003) argues, "only by listening to others can I become aware of the conceptual shackles imposed by my own identity and experiences" (p. 29). The perspectives of others are what allow us to understand our positions in society and make us aware of the assumptions we may unknowingly make about one another based on social, family, neighborhood, sexuality, political, spiritual, economic, and ecological differences and is a critical factor in achieving, "emergence of consciousness and crucial intervention in reality" (Takacs, 2003). We capture this knowledge, skills, and dispositions of critical awareness in our language of perspective taking. An angled perspective does not assume that empathy, or taking on another perspective is necessary (or even possible in many cases). An angled perspective means that we strive to leverage our awareness of our identities and their positionality to affirm that others have complex constellations of identities that differently position them in systems and structures, while cultivating an awareness of our own conceptual shackles.

\section{Building Capacity Through Intersectionality Theory}

Finally, although identity helps students to name their social identities and positionality helps students to understand who they are in relation to the world and others, intersectionality allows us to examine systems of oppression and how this impacts individuals, especially people of color. One of the most important distinctions we make when teaching about intersectionality is that this was a theory created by Black women to highlight Black women's oppression. So, while every student holds a positionality, not every student experiences intersectionality, which focuses on interlocking systems of oppression. (For example, a white man is privileged in both his race and gender- this is positionality, not intersectionality.) It is important, however, for PSTs to learn about intersectionality so that they can 
have this analytic framing to understand how students from multiple minoritized backgrounds (e.g., a Latino student with a disability) might be further marginalized.

Intersectionality theory is credited to Black feminists Kimberlé Crenshaw $(1989,1991)$ and Patricia Hill Collins $(1990,2015)$. Crenshaw originally introduced intersectionality as an analytical tool to argue the need for intersectional inquiry to address the social problem of violence against women of Color. White women did not have the same experiences as Black women and thus a gendered lens alone did not account for the "complexity of the Black experience, for Black women, first of all, and also for Black men" (Dumas \& Ross, 2016, p. 423). Collins (2015) explains, "The term intersectionality references the critical insight that race, class, gender, sexuality, ethnicity, nation, ability, and age operate not as unitary, mutually exclusive entities, but rather as reciprocally constructing phenomena" (p. 1). Collins also explained how one's intersecting identities produce systems of privilege and oppression, which she refers to as a "matrix of domination" (Collins, 2000, p. 19).

Intersectional understandings are important to understanding the complexity of identity discussed above and how this relates to power. Taking up such intersectional understandings of both privileged and oppressed identities, Tatum (2000) explains

People are commonly defined as other on the basis of race or ethnicity, gender, religion, sexual orientation, socioeconomic status, age, and physical or mental ability. Each of these categories has a form of oppression associated with it: racism, sexism, religious oppression/ anti-Semitism, heterosexism, classism, ageism, and ableism, respectively. In each case, there is a group considered dominant (systematically advantaged by the society because of group membership) and a group considered subordinate or targeted (systematically disadvantaged). When we think about our multiple identities, most of us will find that we are both dominant and targeted at the same time. But it is the targeted identities that hold our attention and the dominant identities that often go unexamined. (p. 11)

Similar to the way people's self-identity is mediated from both inside and outside factors, Tatum builds on Collins (2000) notion that multiple identities could either enhance or subdue oppression. Audre Lorde (1992), who is self-described as a "forty-nine-year-old Black lesbian feminist socialist mother of two" (p. 1) also sheds light on the importance of understanding how there is no hierarchy of oppressions:

Somewhere, on the edge of consciousness, there is what I call a mythical norm, which each one of us within our hearts knows "that is not me." In America, this norm is usually defined as white, thin, male, young, heterosexual, Christian, and financially secure. It is with this mythical norm that the trappings of power reside within society. Those of us who stand outside that power often identify one way in which we are different, and we assume that to be the primary cause of all oppression, forgetting other distortion around difference, some of which we ourselves may be practicing. ( $\mathrm{p}$. 446)

Here, Lorde recognizes who is considered to be the "norm" in the U.S. American context and problematizes this for others who fall outside of these identity markers. Amatullah illuminates her own intersectional identities unveiling religion as her salient identity that informs her other complex web of identities. She further sheds light on the struggle maneuvering her complex interplay of intersectionality.

Amatullah. In the past, I reflected on my identity as a Muslim woman, an educator, a daughter, a wife, a mother. But I never really realized this idea of being oppressed as well as privileged conjointly as Ilearned when reading Sensoy and DiAngelo's (2012) text "Is Everyone Really Equal? An Introduction to Key Concepts in Social Justice Education." The authors stress the need to 
"acknowledge the reality that we simultaneously occupy both oppressed and privileged positions and that these positions intersect in complex ways" (p. 115). Hence, now I see my identity is a complex web that positions me as a heterosexual, middle-class, able-bodied Muslim woman who grew up in south of Indian sub-continent, Chennai for the first twenty years of my life and then moved to the Gulf Countries (United Arab Emirates and Qatar) as a resident for more than a decade. Later, as an international doctoral student in the U.S., the part of my identity that was ever subtle becomes my unhidden identity: Religion! Now, as a professor teaching pre-service teachers about diversity issues positions me to constantly reflect on my intersectional identity as I teach predominantly White students about theirs.

As a Muslim scholar, I proudly wear my religious outfit; a long black robe called "abaya" while practicing Islamic teachings irrespective of the geographic contexts I have lived in. Amongst all the other identities in my positionality, I believe that the intersection of my religion plays a very crucial role. It not only influences identity but acts as a core foundation in which my positionality is shaped, I would rather say it is deeply embedded! However, this part of my identity becomes my unhidden identity. I constantly juggle with not just "double consciousness" as Du Bois calls it, I in fact negotiate "multiple consciousness" given my identity as an Asian, Muslim, woman in the U. S. that makes me think not just twice of how I need to operate in this socially constructed society as an educator in the classroom as well as consider what my students would be thinking about me and my dress code. Despite how accepting and understanding the communities have been, there lives a constant fear of islamophobia somewhere within me.

Gender has always been an obvious discrimination ever witnessed during my childhood days in my community from play to chores! My young mind was never critical about gender assigned roles. As religion formed the foundation of all that we did as Muslims, everything was justified from religious perspectives. But now, as I researched more about Islam and different perspectives from a variety of scholars, Ilearned that Islam has been misconceived with cultural practices. In fact, Islam empowers women in their positions and never restrains women to pursue their careers. Racial confusion still perplexes me. Usually when people ask to introduce myself, I refer myself as an Indian Muslim woman, however, "Indian" for me is solely based on geographic location. It was only when I checked the boxes for my doctoral studies applications that I realized this part of identity plays a crucial role in the context of the United States due to its long debated historical, social, and political roots that continue to persist. My privileges fluctuate based on the context I am in and I am cognizant of that in all endeavors. For instance, in the Gulf countries, I was privileged to be a Muslim and belong to the majority that I did not have worry about my religious identity, but this very same identity positions me as a minority and underprivileged in the U.S. context.

Ultimately, reflecting on one's own identity and positionality, I believe, is one of the keys to eradicate social injustices in our society. I echo Bourke (2014) that our "identities come into play via our perceptions, not only of others, but the way in which we expect others will perceive us" (p. 1). This is what really bothers me about functioning in any society where I am evaluated by others on my appearance rather than the "real" me. Furthermore, it is essential not only for educators but for all humans to identify and explore the relationship between oneself and the social groups that we belong to and consider the "interplay of positionality" (Sensoy \& DiAngelo, 2012, p. 24). Martin and Gunten (2002) further argue that it is the responsibility of teacher educators to create awareness among students, "future teachers," about their positionality from their lens as well as from the society's lens. Hence, as an educator, it is crucial for me to keep my positionality and complex intersectional identities in mind while urging them to critically reflect on theirs as future educators in diverse contexts. 
We understand intersectionality to include an examination of how race, gender, sexuality, class, dis/ability, nationality, religion, language, and geography intersect and contribute to a person's experiences in the world as either/both privileged or/and oppressed (Grant and Z wier 2011; Sensoy and DiAngelo 2012). While theorized from Black feminist thought designed to complicate the collection of social identities, intersectional definitions of oneself aid PSTs in better understanding their privileged and marginalized selves. Collins (2015) reminds us that other affinity groups have taken up intersectionality theory to explore their own "reciprocally constructing phenomena that in turn shape complex social inequalities" (p. 2). This is no less true for affinity groups within teacher education, including PSTs of color, PSTs who are queer identified, or PSTs teachers who hold non-Christian ethnic or religious identities- and all the ways these might intersect.

\section{Implications of Building Capacity for Angled Perspectives}

The three theoretical frameworks that informed this article - identity theory, intersectionality theory, and positionality theory - aid in understanding how we come together in our own reflection and how we approach teaching PST in our multicultural education courses about critical reflexivity. As we stated previously, we conceptualize angled perspective-taking as a practice that operationalizes positionality theory - where educators leverage their awareness of the complex relationship between their own identities and systems of power (intersectionality). Then, educators can leverage that awareness to recognize their students' complex realities and access to resources, especially across identity differences. Building capacity for angled perspective-taking requires a well-developed awareness of one's own identities, positionality, and intersectionality. We believe that intentional and critical teacher preparation to develop teachers' capacity for angled perspective is necessary, although a partial answer to that pressing need. As long as diversity gaps exist between teachers and students, building PSTs capacity for angled perspective-taking becomes even more important. To integrate angled perspective into teacher education, teacher educators, in particular white teacher educators, need to develop their own capacity and model this for PST. The question we must ask is how does teacher education build its own capacity to help educators across differences develop an angled perspective?

We argue a critical step toward developing capacity for angled perspective-taking is for teacher educators to engage in the ongoing practice of critical reflection, to gain an understanding of the self in relation to the world (Gay \& Kirkland, 2003; Howard, 2003). A structured approach to this professional learning is important to fostering a sustainable cycle of critical reflection. For example, Dismuke, Enright, and Wenner (2018), teacher educators collaborating as critical others, framed their reflection on their feedback practices in hybrid teacher education spaces through a five-level heuristic of teacher educator reflection (Nelson \& Sadler, 2013), which culminates in personalistic reflection focused on critical self-examination with the aim of improving one's own practice (Vali, 1997). After engaging in that formal reflection process, they extended that learning by making their findings public to problematize their current practices with a broader group of colleagues (e.g., conference presentations, publications, internal teacher education meetings, etc.). Finally, they used their findings from the cycle of reflection to make changes in their practice and inform future cycles of reflection. This structured approach to reflection provides an accessible vehicle through which teacher educators can develop their capacity for angled perspective-taking.

Enacting a cycle of reflection requires that teacher educators cultivate relationships with colleagues willing and capable of giving and receiving feedback as critical others to support learning (Dismuke et 
al., 2018). This reflective work should be informed by teacher candidates' perspectives to disrupt, confirm, and extend the reflective cycles (Bullock, 2017). In other terms, teacher educators need to undertake to learn as well as teach angled perspective-taking. Teacher educators' professional learning becomes a form of modeling for their PSTs. In addition, teacher educators, in particular those with privileged identities, need to make space and learn from the perspectives of their colleagues from marginalized affinity groups. Teacher educators need to undertake this learning with humility, vulnerability, and authenticity as part of a formal cycle of critical reflection. Critical identity work is often risky and painful, and it is past time that educators with privileged identities, in particular white educators, should be engaging in this professional learning alongside their colleagues with marginalized identities, in particular educators of color.

So, what is the next step? How can teacher educators, once they practice engaging in angled perspective-taking in their own professional learning, teach preservice (and practicing) teachers to do the same? Teacher educators need to read about identity development with their PSTs. As we shared above, we are informed by identity theory, intersectionality theory, and positionality theory in both our teaching and within our own lives that have shaped our angled perspectives. As former teachers ourselves, we have each gone through the process of discovering our identity, positionality, and relationship to intersectionality that shapes our pedagogies today. Picower and Kohli (2017) argue that "much like the raced, classed, and gendered identities of students and teachers, the identity of a teacher educator also inevitably anchors and shapes their approaches to racial justice" (p. 7). We operationalize our conceptual framework by sharing our own understandings of how our intersecting identities revealed our positionality thus our angled perspectives.

Next, teacher educators need to make space for PSTs to explore their own identities - not just learn about others' - throughout their teacher preparation programs. As teacher educators, we cannot leave the likelihood of students with privileged identities exploring their own whiteness and other privileged identities or building capacity to teach students across identity differences to chance. A crucial part of teacher education's mandate is to help teachers develop an understanding of their identities as it relates to their students given the demographic divide (e.g., Gordon, 2005; Martin \& Van Gunten, 2002). Teacher education needs to refocus on building capacity to fulfill this. Understanding teacher development in coursework, specifically as it relates to teacher identity can aid us in understanding "consciousness-raising" as a significant tool in teacher preparation (Olsen, 2011, p. 268). Studies in teacher identity development, mostly focused on racial awareness, demonstrate that teacher identity is not fixed; rather it is dynamic and shares a relationship between a "core identity and multiple selves;" it is "both a process and a product;" it involves conversations among self, others, history, and professional contexts; and it is political and socially situated (Olsen, 2011, p. 257). We also acknowledge a need to consider this process across many different social identities.

Finally, as evidenced through the conceptual framework that shapes our teaching, we argue that angled perspective can be reached through intentional conversations and dialoguearound identity. We assert that white students, and PSTs with other privileged identities, need to be pushed while simultaneously supported in their exploration of their privilege, while also acknowledging the intersections that exist. It is important to acknowledge that because the journey in learning about positionality is different for everyone. As we have learned in our own teaching, we acknowledge the different risks for instructors of color and instructors holding multiple targeted identities inevitably face undertaking this work. Thus, it is more important than ever for teacher educators (just as practicing and preservice teachers) with privileged identities to work in solidarity with instructors of multiple targeted identities to unpack their own positionality and develop capacity for angled perspective through 
discussions and critical reflection of their experiences, better positioning them to help students develop angled perspective. We need to listen so that we can understand.

If angled perspective is learnable, then it is also teachable. Advancing the argument that angled perspective as a learnable skill opens the door to investigations on how faculty teaching multicultural education courses can skillfully teach practice to novices to build their students' capacity for angled perspectives. While teacher education wrestles (or fails) to create space for teachers of color, the field also needs to prepare the overwhelmingly white, mono-lingual, Christian teaching force we have to teach an increasingly diverse student population skillfully and respectfully across identity differences. Preparing white educators, in particular, to develop and use angled perspective, as Delpit (2012) says, to learn to see students of color "as brilliant as those from any well-to-do white community" (p. 5) is urgent, immediate work that cannot wait for larger revolutions.

\section{Declaration of Conflicting Interests}

The author declared no potential conflicts of interest with respect to the research, authorship, and/or publication of this article.

\section{Funding}

The authors received no financial support for this research.

\section{ORCID iD}

Brittany A. Aronson (D) https://orcid.org/0000-0002-0531-6544

Esther A. Enright (D) https://orcid.org/0000-0003-0844-5584

Tasneem Amatullah (iD https://orcid.org/0000-0003-0715-6836

\section{References}

Adichie, C. (2009). The danger of a single story [Video]. TED Conferences. https://www.ted.com/talks/chimamanda_adichie_the_danger_of_a_single_story

Alcoff, L. (1988). Cultural feminism versus post-structuralism: The identity crisis in feminist theory. Signs, 13(3), 405-436. https://doi.org/10.1086/494426

Bailey, A. (1998). Locating traitorous identities: toward a view of privilege-cognizant White character. Hypatia, 13(3), 27-42. https://doi.org/10.1111/j.1527-2001.1998.tb01368.x

Bartlett, K. (1990). Feminist legal methods. Harvard Law Review, 103(4), 829-888. https://doi.org/10.2307/1341478

Belkhir, J., Griffith, S., Sleeter, C., \& Allsup, C. (1994). Race, sex, class and multicultural education: Women's angle of vision. Race, Sex \& Class, 1(2), 7-22. https://www.jstor.org/stable/41680218

Boser, U. (2014). Teacher diversity revisited: A new state-by-state analysis. Center for American Progress. https://cdn.americanprogress.org/wpcontent/uploads/2014/05/TeacherDiversity.pdf

Bourke, B. (2014). Positionality: Reflecting on the research process. The Qualitative Report, 19(33), 19. https://doi.org/10.46743/2160-3715/2014.1026 
Bullock, S. (2017). Understanding candidates' learning relationships with their cooperating teachers: A call to reframe my pedagogy. Studying Teacher Education, 13(2), 179-192. https://doi.org/10.1080/17425964.2017.1342355

Collins, P. (1990). Black feminist thought: Knowledge, consciousness, and the politics of empowerment. Unwin Hyman.

Collins, P. (2000). Black feminist thought: Knowledge, consciousness, and the politics of empowerment. Routledge.

Collins, P. (2015). Intersectionality's definitional dilemmas. Annual Review of Sociology, 41, 1-20. https://doi.org/10.1146/annurev-soc-073014-112142

Crenshaw, K. (1989). Demarginalizing the intersection of race and sex: A black feminist critique of antidiscrimination doctrine, feminist theory and antiracist politics. University of Chicago Legal Forum, 1989(1), 139-167.

Crenshaw, K. (1991). Mapping the margins: intersectionality, identity politics, and violence against women of color. Stanford Law Review. 43(6), 1241-1299.

https://doi.org/10.2307/1229039

Cross, B. (2003). Learning or unlearning racism: Transferring teacher education curriculum to classroom practices. Theory into Practice, 42(3), 203-209. https://doi.org/10.1207/s15430421tip4203 6

Darling-Hammond, L. (2011). Foreword. In A.. Ball and C. Tyson (Eds.) Studying diversity in teacher education. Rowman \& Littlefield.

Delpit, L. (2012). "Multiplication is for white people": Raising expectations for other people's children. The New Press.

Dismuke, S., Enright, E., \& Wenner, J. (2018). It's a balancing act: A self-study of teacher educators' feedback practices and the underlying tensions. In D. Garbett and A. Ovens (Eds.) Pushing boundaries and crossing borders: Self-study as a means for knowing pedagogy (pp. 35-41). Self-Study of Teacher Education Practices (S-STEP).

Dumas, M., \& Ross, K. (2016). "Be real black for me" Imagining BlackCrit in education. Urban Education, 51(4), 415-442. https://doi.org/10.1177/0042085916628611

Garmon, M. (2004). Changing preservice teachers' attitudes/beliefs about diversity: What are the critical factors? Journal of Teacher Education, 55(3), 201-213. https://doi.org/10.1177/0022487104263080

Gay, G. (2002). Preparing for culturally responsive teaching. Journal of Teacher Education, 53(2), 106-116. https://doi.org/10.1177/0022487102053002003

Gay, G., \& Kirkland, K. (2003). Developing cultural critical consciousness and self-reflection in preservice teacher education. Theory into Practice, 42(3), 181-187. https://doi.org/10.1207/s15430421tip4203 3

Grant, C. A., \& Zwier, E. (2011). Intersectionality and student outcomes: Sharpening the struggle against racism, sexism, classism, ableism, heterosexism, nationalism, and linguistic, religious, and geographical discrimination in teaching and learning. Multicultural Perspectives, 13(4), 181188. https://doi.org/10.1080/15210960.2011.616813

Gordon, J. (2005). Inadvertent complicity: Colorblindness in teacher education. Educational Studies, 38(2), 135-153. https://doi.org/10.1207/s15326993es3802 5

Haraway, D. (1988). Situated Knowledge: The science question in feminism and the privilege of partial perspective. Feminist Studies, 14(3), 575-599. https://doi.org/10.2307/3178066 
Harding, S. (1986). The science question in feminism. Cornell University Press.

Harding, S. (1991). Whose science? Whose knowledge? Thinking from women's lives. Cornell University Press. https://doi.org/10.7591/9781501712951

Howard, T. (2003). Culturally relevant pedagogy: Ingredients for critical teacher reflection. Theory into Practice, 42(3), 195-202. https://doi.org/10.1207/s15430421tip4203 5

Irvine, J. (1990). Black students and school failure. Greenwood.

Johnson, L. (2002). "My eyes have been opened": White teachers and racial awareness. Journal of Teacher Education, 53(2), 153-167. https://doi.org/10.1177/0022487102053002007

Jupp, J., Berry, T., \& Lensmire, T. (2016). Second-wave white teacher identity studies: A review of white teacher identity literatures from 2004 through 2014. Review of Educational Research, 86(4), 1151-1191. https://doi.org/10.3102/0034654316629798

Ladson-Billings, G. (2001). Crossing over to Canaan: The journey of new teachers in diverse classrooms. Jossey-Bass.

Ladson-Billings, G. (2004). Landing on the wrong note: The price we paid for Brown. Educational Researcher, 33(7), 3-13. https://doi.org/10.3102/0013189X033007003

Lorde, A. (1992). Age, race, class, and sex: Women redefining difference. In M. Andersen \& P. Hill Collins (Eds.), Race, class, and gender: An anthology (pp. 495-502). Wadsworth.

King, J. (1991). Dysconscious racism: Ideology, identity, and the miseducation of teachers. The Journal of Negro Education, 60(2), 133-146. https://doi.org/10.2307/2295605

Liu, K., \& Ball, A. (2019). Critical reflection and generativity: Toward a framework of transformative teacher education for diverse learners. Review of Research in Education, 43(1), 68-105. https://doi.org/10.3102/0091732X18822806

Maher, F., \& Tetreault, M. (1994). The feminist classroom: An inside look at how professors and students are transforming higher education for a diverse society. Basic Books.

Martin, R., \& Van Gunten, D. (2002). Reflected identities: applying positionality and multicultural social reconstructionism in teacher education. Journal of Teacher Education, 53(1), 44-54. https://doi.org/10.1177/0022487102053001005

Marx, S. (2003). Reflections on the state of critical white studies. International Journal of Qualitative Studies in Education, 16(1), 3-5. https://doi.org/10.1080/0951839032000033491

McLaren, P. (1997). Revolutionary multiculturalism: Pedagogies of dissent for a new millennium. Westview.

Milner, H. (2010). What does teacher education have to do with teaching? Implications for diversity studies. Journal of Teacher Education, 61(1-2), 118-131. https://doi.org/10.1177/0022487109347670

Moll, L., Amanti, C., Neff, D., \& Gonzalez, N. (1992). Funds of knowledge for teaching: Using a qualitative approach to connect homes and classrooms. Theory into Practice, 31(2), 132-141. https://doi.org/10.1080/00405849209543534

Nelson, F., \& Sadler T. (2013). A third space for reflection by teacher educators: A heuristic for understanding orientations to and components of reflection, Reflective Practice, 14(1), 43-57. https://doi.org/10.1080/14623943.2012.732946

Olsen, B. (2011). "I am large, I contain multitudes" Teacher identity as a useful frame for research, practice, and diversity in teacher education. In A. Ball and C. Tyson (Eds.), Studying diversity in teacher education, (pp. 257-273). Rowman \& Littlefield.

Picower, B., \& Kohli, R. (Eds.). (2017). Confronting racism in teacher education: Counternarratives of critical practice. Routledge. https://doi.org/10.4324/9781315623566 
Rubin, D. (2017). Whiter shade of pale: Making the case for Jewish presence in the multicultural classroom. International Journal of Multicultural Education, 19(2), 131-145. http://doi.org/10.18251/ijme.v19i2.1415

Sensoy, Ö., \& DiAngelo, R. (2012) Is everyone really equal? :an introduction to key concepts in social justice education. Teachers College Press.

Sleeter, C. (2001). Preparing teachers for culturally diverse schools: Research and the overwhelming presence of whiteness. Journal of Teacher Education, 52(2), 94-106. https://doi.org/10.1177/0022487101052002002

Stohry, H. \& Aronson, B., (2021). A negotiated relationship: Nuances of "whitened" biracial educator identities. Educational Studies, 57(1). 1-20. https://doi.org/10.1080/00131946.2020.1863801

Takacs, D. (2003). How does Your positionality bias your epistemology? Thought \& Action, 19, 2738. https://repository.uchastings.edu/faculty scholarship/1264

Talbert-Johnson, C., \& Tillman, B. (1999). Perspectives on color in teacher education programs: Prominent issues. Journal of Teacher Education, 50(3). 200-208. https://doi.org/10.1177/002248719905000306

Tatum, B. (2000). The complexity of identity: Who am I. in M. Adams (Ed.), Readings for diversity and social justice (pp. 9-14). Routledge.

Terrill, M., \& Mark, D. (2000). Preservice teachers' expectations for schools with children of color and second-language learners. Journal of Teacher Education, 51(2), 149-155. https://doi.org/10.1177/002248710005100209

Tieken, M. (2014). Why rural schools matter. University of North Carolina Press.

Ullucci, K. (2011). Learning to see: the development of race and class consciousness in white teachers. Race Ethnicity and Education, 14(4), 561-577. https://doi.org/10.1080/13613324.2010.519982

Ward, E. (June 2017). Skin in the game: How antisemitism animates white nationalism. The Public Eye. http://www.politicalresearch.org/2017/06/29/skin-in-the-game-how- antisemitism-animateswhite-nationalism/

Wood, J. (1992). Gender and moral voice: Moving from woman's nature to standpoint epistemology. Women's Studies in Communication, 15(1), 1-24. https://doi.org/10.1080/07491409.1992.11089757 